\title{
TÕE-LINE FÜÜSIKA JA TÕELINE FÜÜSIKA
}

\author{
PIRET KUUSK
}

$\mathrm{F}$ üüsikat peetakse tõe-liseks teaduseks, mille väidetavad seaduspärasused peavad olema tõesed, sest neil põhinevad kokkuvõttes kõik need kõrgtehnoloogilised seadmed, mis meie ümber ja meie käes töötavad suhteliselt stabiilselt.

Esimene küsimus: mida siin mõista tõesuse all? Kõige loomulikum vastus tundub olevat: väide, et asjad on nii, on tõene, kui asjad ongi nii. Sarnaselt selgitas tõde juba Aristoteles oma „Metafüüsikas”: öelda oleva kohta, et see on, või mitteoleva kohta, et seda ei ole, on tõene.

Kuid siis kerkib kohe järgmine küsimus: kust sa tead, et asjad maailmas ongi nii, nagu väites on väidetud?

Erinevalt Aristotelesest ei hakka uusaja füüsikud alates Galileist selle üle arutlema, vaid asuvad tegutsema, täpsemalt, tegema vaatlusi, mõõtmisi ja katseid. Tegu ja sõna on kaks võimet, mis on inimesele loomulikul viisil omased. Füüsikas on need kaks sellisel viisil kooskõlastatud, või vähemalt püütud kooskõlastada, et kokkuvõttes on meil katsetulemustel põhinevad füüsikateooriad, millele saab üles ehitada kogu meie kõrgtehnoloogilise keskkonna.

Väide, et füüsika on tõe-line, st kirjeldab maailma tõeselt, paistab olevat probleemitu ja igati õigustatud.

Kuid nagu ikka, mitte kõik ei ole nii, nagu paistab.

Seni kuni füüsikud tegid katseid seadeldistega, mida nad oma kätega üles ehitasid, ja mõõtsid objekte, mis olid otse nende silma all, võis tõesti olla nii, et nende väiteid maailma asjaolude kohta ja maailma asjaolusid endid sai suhteliselt lihtsasti võrrelda. Kui nendevaheline vastavus oli vähemalt rahuldav, siis tunnistati väide tõeseks, või täpsemalt, tõeseks tõe vastavusteooria kohaselt.

Kuid tänapäeva füüsika tahab midagi väita mitte ainult inimese suurusjärgus oleva kohta, selle praegune haare ulatub mikromaailmast kuni universumini, $10^{-24}$ meetrit (1 MeV energiaga neutriino hajumise ristlõige) kuni $10^{27}$ meetrit (meile nähtava universumi raadius). See tähendab, et vastus küsimusele „Kust sa tead?" muutub vahetust ja iseenesestmõistetavast, vägagi vahendatuks.

Niisiis, kust füüsikud saavad teada selle, mida nad oma teooriates väidavad ja rahvale aimekirjanduses jutustavad?

Uusaegne füüsika koosneb kahest mõnevõrra erinevast osast: eksperimentaalfüüsikast ja teoreetilisest füüsikast. Eksperimentaalfüüsikas tekitatakse eesmärgipäraselt erilisi olukordi maailmas ja mõõdetakse nende olukordade meid huvitavaid omadusi. Katsete tulemusteks on mõõtarvude hulgad, mis tänapäeva arvutiajastul võivad olla hoomamatult suured. Kuid arvuhulgad iseeneses ei anna meile soovitud teadmist maailma kohta. See, mida soovitakse, on füüsikaline maailmapilt, mille saamiseks tuleb erinevad arvuhulgad kõigepealt lasta läbi andmetöötluseks nimetatud masinavärgi ja sealt leitud järeldused siduda kokku teatud tervikuks. Seda ülesannet täidab teoreetiline füüsika, mis mõõtarvude tähendusest lähtudes ehitab nendest struktuuri ja 
sageli lisab ka sõnalise seletuse, ehk teisisõnu, esitab sidusa teooria kõnealuste olukordade kohta. Kuna see tegevus kokkuvõttes lähtub mõõtarvude hulkadest, siis on teooriad suures osas matemaatilised ja kõige selgemini kirjeldatavad matemaatiliste valemite abil. Niisiis, kui eksperimentaalfüüsika on teatud tüüpi tegevus, siis teoreetiline füüsika on selle tegevuse tulemuste kokkuvõtlik kirjeldamine sobiva matemaatilise mudeli abil. Tegelikus füüsikateaduses ei ole piir eksperimentaal- ja teoreetilise füüsika vahel muidugi nii selge, kuid siiski tuleb tunnistada, et füüsikaalane teadmine ei ole mitte niivõrd teadmine otseselt maailmast ja meie katsetegevusest maailmas, kuivõrd teadmine teoreetilistest mudelitest maailma ja katsetulemuste kohta.

Mis on mudel? Üldiselt võib seda määratleda kui ühe süsteemi esitust teise, lihtsama süsteemina, mille toimimist peetakse esimesega sarnaseks. Füüsikas, nagu juba öeldud, on laialt kasutusel matemaatilised mudelid, kus tegelike ja võimalike katsete tulemused on kokku seotud sobivalt interpreteeritud matemaatikavalemiteks. Vähem olulised on kõikvõimalikud piltlikud kujutlused, mis aga siiski võivad olla heuristilised abivahendid.

Niisiis võib öelda, et füüsika vahetu uurimisobjekt ei ole mitte niivõrd maailm, kuivõrd maailma mudelid. Siit aga kohe uus küsimus: mida tähendab, et mudel on tõene, ja kas nii saab üldse küsida? On selge, et mudeli ennustusi tuleb võrrelda võimalikult paljude võimalikult erinevate tegelike katsete ja vaatluste tulemustega. Kui ennustused on nendega rohkem või vähem kooskõlas, on mudel rohkem või vähem rahuldav. Enamasti hinnatakse kooskõla kvantitatiivselt, st arvuliselt, võrreldes mudelarvutusi tegelikult saadud mõõtarvudega. Kui erinevused on suured, tuleb vastav teooria kui mittekõlblik kõrvale jätta, ükskõik kui hästi ta ka ei kirjeldaks ega seletaks neid katsetulemusi, mille alusel ta esitati.

Niisugune skeem on teadusfilosoofias tuntud kui deduktiiv-nomoloogiline seletus: eeldatakse teatud üldise seaduspära (või mudeli) olemasolu ja uute tegelike katsete tulemusi loodetakse tõlgendada selle erijuhtudena. Kahjuks on see skeem liiga ilus, et olla enamikel juhtudel rakendatav.

Näide elust enesest: neutriinod ja valguse kiirus. Aastail 2011-2012 levis mitteametlikes teaduskanalites Genfis asuva Euroopa Tuumauurimiskeskuse teade, et üks nende katse olevat näidanud neutriinode levikiirust suuremana kui valguse kiirus, mis erirelatiivsusteooria järgi on suurim võimalik kiirus. Otsekohe ilmus suur hulk teoreetilisi töid, kus esitati rohkem või vähem põrutavaid ideid, kuidas muuta erirelatiivsusteooriat ja elektrodünaamikat nii, et valguse kiirusest suuremad kiirused oleksid lubatud. See tähendab: taheti leida uus üldine seaduspära, millest saaks järeldada neutriinode kiiruse mõõdetud väärtust. Kuid õnnetuseks selgus mõne kuu pärast, et tulemuse põhjustas katsekorralduse elektriühenduste ebakvaliteetsus ja valguse kiirust neutriinod ei ületanud. Siiski pole neil autoritel tarvis tunda piinlikkust oma mõttetuks osutunud tööde pärast, sest tegemist oli tavapärase eesliinifüüsikaga, mis arenebki sellisel katse-eksituse meetodil. Odavam on kõik teoreetilised võimalused läbi arvutada, enne kui kalleid katseseadmeid ehitama hakata. Tänapäeva füüsika eesliinitegevus pole kindlasti mingitest alusprintsiipidest järelduste tegemine ja nende katseline kontrollimine. Pigem on märgata pudrupaja moodi podisemist, kust alatasa kerkib uusi ootamatuid küsimusi, ükskõik siis, kas uutest või parandatud katsetulemustest või mõne teooria 
nurgatagustest. Neile küsimustele pakutakse kõikvõimalikke vastuseid, millest paljud on ad hoc, lootuses, et ehk hiljem selgub, millisest uuest seni veel tundmatust üldisemast teooriast saaks neid järeldada. Neutriinode lugu on siin hea illustratsioon: eksperimentaatorid vihjasid väga ettevaatlikult valguse kiirust ületavate neutriinode olemasolu võimalikkusele, sellele järgnes hulk teooriamulle, kuidas seda seletada. Kuna aga katsetulemused ei leidnud kinnitust, siis ainult mullideks need ettepanekud jäidki, mingit uut teooriat esitada ei olnud tarvis.

Sellest loost võib teha kaks järeldust. Esiteks, eesliinifüüsika koosneb mitmesugustest teooriamudelitest, mis peavad olema kooskõlas katsete ja vaatluste tulemustega, kuid harva julgeb keegi väita, et „tegelikkus” on just täpselt niisugune, nagu mudelid kirjeldavad. "Tegelikkuse” olemasolu on muidugi vaikiv eeldus; püüdmata anda selle täpsemat määratlust, on ta olemas vähemalt kui keskkond, milles katseseade asub. Teiseks, juba antiikajast on tuntud teadmiste alamääratuse tees: kogemus üksi ei määra kirjeldust. Ehk kaasaegse füüsika kohta: eesliinifüüsika võib olla pluralistlik, samu tulemusi kirjeldavad erinevad mudelid.

Kuid eesliinifüüsika mõiste ise sisaldab endas muutust: eesliin liigub ees ja tema järel on kogu aeg kasvav tagala. Just füüsika tagala on see, mis kokkuvõttes toodab meie kõrgtehnoloogilist keskkonda. See peab koosnema töötavatest seadmetest, mis kinnitaks tagala positsiooni jõudnud füüsika mõttekust. Ei ole enam oluline, missuguse tõeteooria järgi tuleks sealset füüsikat tõeseks tunnistada ja mis mõttes üldse võiks ta olla väär, kui aparaadid ja masinad töötavad meie kasuks just nii, nagu nad on kavandatud.

See tõeks tunnistamine lõpetab arutluse tõe-lise füüsika üle, kuid kutsub edasi mõtlema tõelise füüsika üle, st küsima, mis on füüsika üldisem tähendus ja koht. Füüsikafilosoofias on praegu eristatud kolme võimalikku lähenemisviisi (Crease 2017: 19):

1) analüütiline - kõige olulisemaks peetakse füüsikaalaste teadmiste sisemist loogikat, selle meetodite ja mõistete süsteemi struktuuri ja toimimist (Carnap, Russell), füüsikud on füüsikateaduse loogika selgitajad;

2) pragmaatiline - vaadatakse, kuidas füüsikud lahendavad maailmas esile kerkinud probleeme ja mõistatusi ning kuidas need lahendused mõjutavad meie suhteid maailmaga (Peirce, William James, Dewey), füüsikud on looduse mõistatuste lahendajad;

3) kontinentaalne - teadustegevust vaadatakse kui üht eluviisi kõikvõimalike teiste seas ja soovitakse arvesse võtta ka seda, mis ei ole otseselt mõõdetav ega manipuleeritav, nt metafoore, traditsioonilisi kombeid, alateadvuslikke kujutlusi jms (Husserl, Heidegger), füüsikud toovad nähtavale ainult selle osa maailmast, mis on ratsionaalselt arusaadav ja manipuleeritav, ning jätavad kõrvale kõik muu.

Kui analüütilise traditsiooni esindajate jaoks on üldiselt vastuvõetav vaade füüsikale kui mudelite kogule, siis eriti just kontinentaalses traditsioonis püütakse leida sügavamaid aluseid ja põhjendusi täppisteadusliku füüsika vaieldamatule edukusele. Näiteks on Martin Heidegger (1989) oma arutlustes tehnika üle puudutanud ka täppisteadusliku füüsika ja tehnika vahekorda. Tema nägemuses on tehnika olemus maailma väljatoomine varjatusest ja selle esitamine (energia) tagavarana meie jaoks. Uusaegne füüsika, mis on paar 
sajandit vanem kui uusaegne tehnika, kehastas tehnika olemust juba enne tehnikat. Seega on füüsika olemus samuti varjatu esiletoomine. Tehnika toetub füüsikale ja kasutab tema täppisarvutusi, kuid ei ole seesama mis füüsika. Nad mõlemad on varjatu esiletoomise viisid.

Sarnast mõtet matemaatilisest alusfüüsikast kui varjatuga silmitsi seismisest on väljendanud teoreetilise alusfüüsika korüfee Madis Kõiv akadeemik Harald Kerese 75. sünnipäeva seminaril 16. novembril 1987 Eesti TA Füüsika Instituudis:

„Teoreetiline uuring selles piirkonnas, millest ma räägin, st alusfüüsikas, ei ole matemaatika rakendamine tavalises tähenduses, see on matemaatika ise tema ideede tasandil. Seal on matemaatilisus alati avantüristlik ja tema vahekord range ametkondliku formaalsusega külm. Ehk kui parafraseerida Einsteini: matemaatika ideedest on pooled pärit füüsikast, st loodusest, st Jumalast, teine pool on loodud matemaatikute kui klaaspärlimängijate suletud ordu enda poolt. Alusfüüsikalistes uuringutes esineb piltlikult rääkides piirsituatsiooni olukordi, kus uurija tunneb, et ta otse ja vahetult mängib tundmatu endaga - mingit superbridži, kus kaartide hulk ja mängureeglid võivad igal ajal muutuda, seda mängu mängitakse sealpool muutuva matemaatika reeglite järgi. Alles hiljem võib neid reegleid kanoniseerida: algebra, diferentsiaalarvutus, diferentsiaalvormid, diferentsiaalgeomeetria, rühmateooria, kihtruumid, topoloogia."1

Olgugi et Madis Kõiv tõi Eestisse mitmed analüütilise filosoofia põhiteemad, haakub tema nägemus alusfüüsikast pigem kontinentaalse filosoofia mõtteviisiga. Küllap on tõelises füüsikas oma koht ja tähendus kõigil kolmel filosoofilisel hoiakul.

\section{Kirjandus}

Crease, Robert P. 2017. Critical point: What philosophers do. - Physics World, kd 31, nr 11, lk 19.

He i d e g g e r, Martin 1989. Küsimus tehnika järele. Tlk Ülo Matjus. - Akadeemia, nr 6, lk 1195-1222.

Piret Kuusk (snd 1947), PhD, Tartu Ülikooli teoreetilise füüsika osakonna vanemteadur(W. Ostwaldi 1, 50411 Tartu),piret.kuusk@ut.ee

\section{True physics and actual physics}

Keywords: philosophy of physics, theories of physics, physical world-view

The essay reviews briefly relation of contemporary theoretical physics to the truth and describes various philosophical approaches to physical knowledge.

Piret Kuusk (b. 1947), PhD, University of Tartu, Department of Theoretical Physics, Senior Research Fellow (W. Ostwaldi 1, 50411 Tartu), piret.kuusk@ut.ee

\footnotetext{
${ }^{1}$ Ettekande käsikiri asub autori isiklikus arhiivis.
} 